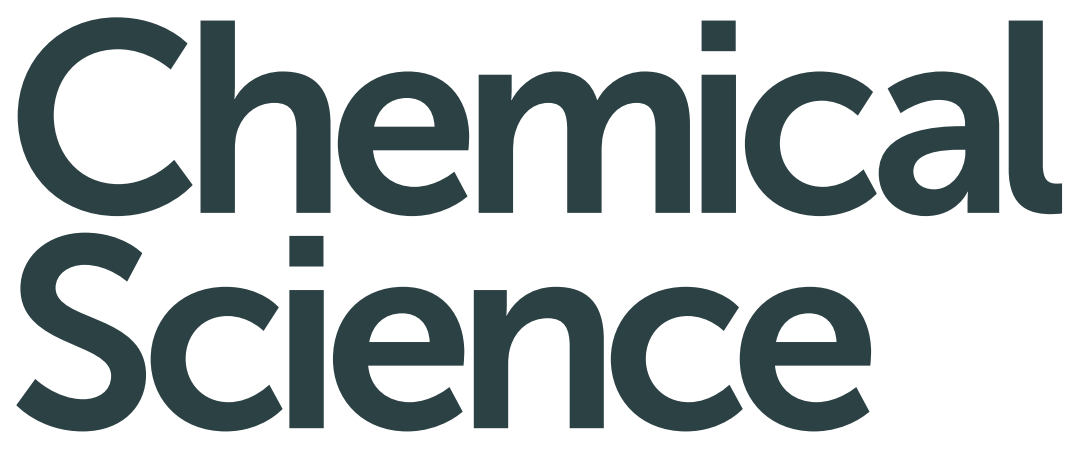

rsc.li/chemical-science

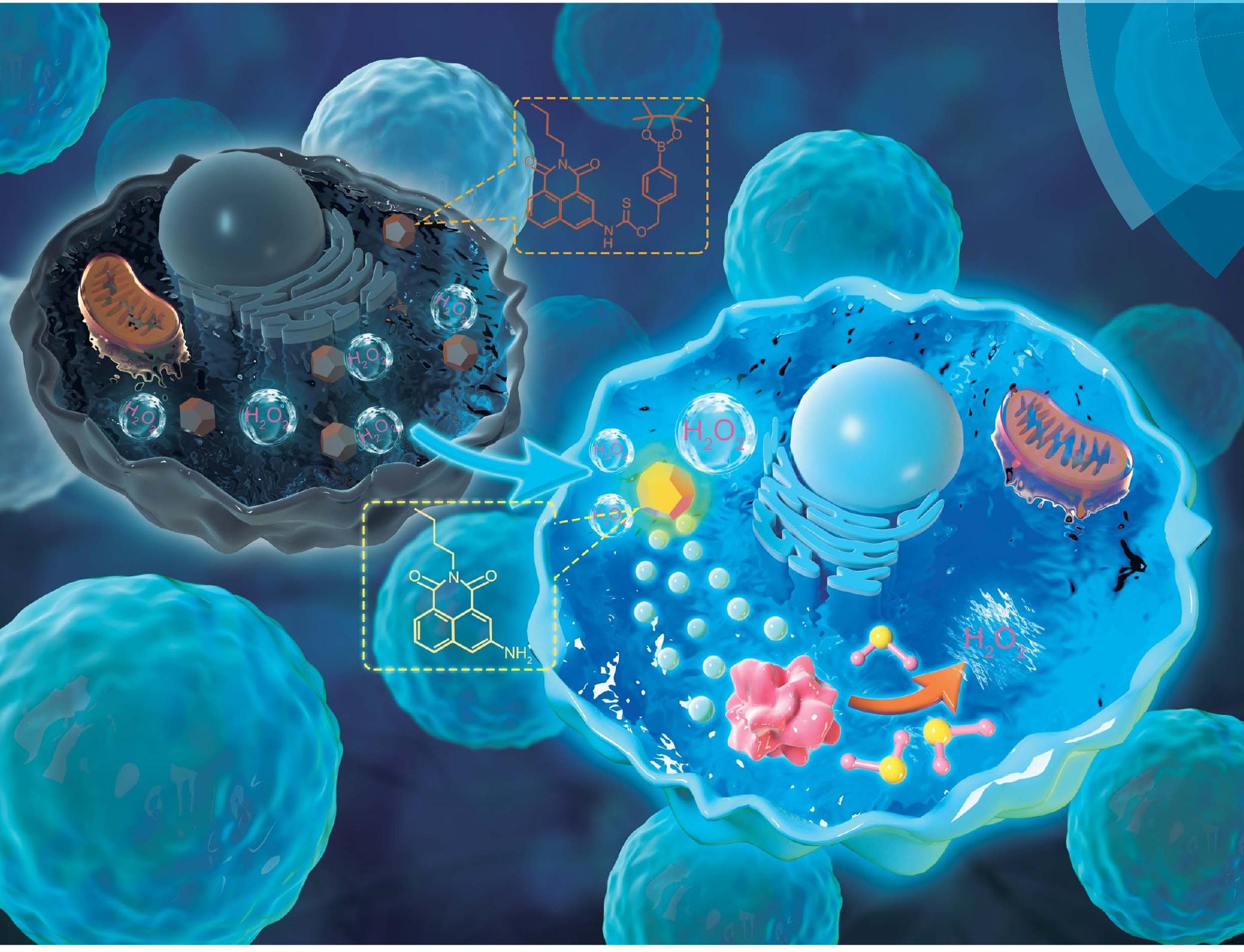

ISSN 2041-6539

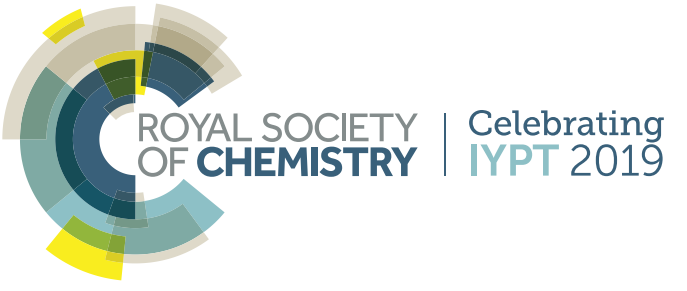


Check for updates

Cite this: Chem. Sci., 2019, 10, 7690

¿ All publication charges for this article have been paid for by the Royal Society of Chemistry
Received 13th May 2019

Accepted 8th July 2019

DOI: $10.1039 / c 9 s c 02323 b$

rsc.li/chemical-science

\title{
Reactive oxygen species-triggered off-on fluorescence donor for imaging hydrogen sulfide delivery in living cells $\dagger$
}

\author{
Yiming Hu, ${ }^{\text {ab }}$ Xiaoyi Li, ${ }^{a}$ Yu Fang, ${ }^{a}$ Wen Shi, (D) ${ }^{\text {ab }}$ Xiaohua Li, (D) ${ }^{a}$ Wei Chen, ${ }^{c}$ \\ Ming Xian (D) ${ }^{c}$ and Huimin Ma (D) *ab
}

\begin{abstract}
Hydrogen sulfide $\left(\mathrm{H}_{2} \mathrm{~S}\right)$, an important gasotransmitter, can mediate a variety of pathophysiological processes, and $\mathrm{H}_{2} \mathrm{~S}$-based donors have been intensively explored for the therapy of cardiovascular injury, nerve damage and intestinal disorders. However, most of the $\mathrm{H}_{2} \mathrm{~S}$ donors are not capable of simultaneously real-time tracking intracellular $\mathrm{H}_{2} \mathrm{~S}$ delivery, which limits their biological application for elucidating the specific function of $\mathrm{H}_{2} \mathrm{~S}$. Herein we develop the first reactive oxygen species (ROS)triggered off-on fluorescence $\mathrm{H}_{2} \mathrm{~S}$ donor (NAB) by incorporating ROS-responsive arylboronate into a fluorophore through thiocarbamate. The donor NAB can release carbonyl sulfide (COS) and the fluorophore with a fluorescence off-on response via a ROS-triggered self-immolative reaction, and then $\mathrm{COS}$ is quickly converted to $\mathrm{H}_{2} \mathrm{~S}$ by the ubiquitous carbonic anhydrase. This dual function makes NAB suitable for not only in situ and real-time monitoring of the intracellular $\mathrm{H}_{2} \mathrm{~S}$ release but also rescuing RAW264.7 cells from the hazardous oxidative environment under the stimulation of phorbol-12myristate-13-acetate, revealing the possible potential of NAB as a therapeutic prodrug with the fluorescence imaging capacity.
\end{abstract}

\section{Introduction}

Hydrogen Sulfide $\left(\mathrm{H}_{2} \mathrm{~S}\right)$ is an important gasotransmitter, which can mediate a variety of physiological and pathological processes. Recent studies have demonstrated that $\mathrm{H}_{2} \mathrm{~S}$ is associated with iron homeostasis, ${ }^{1}$ vasodilation ${ }^{2}$ and neurotransmission. ${ }^{3}$ Modulation of $\mathrm{H}_{2} \mathrm{~S}$ levels is suggested to have potential therapeutic value. However, further understanding the biological function of $\mathrm{H}_{2} \mathrm{~S}$ remains an open challenge due to the lack of effective tools to modulate and monitor cellular $\mathrm{H}_{2} \mathrm{~S}$ levels. Some inorganic sulfide salts $\left(\mathrm{NaSH}, \mathrm{Na}_{2} \mathrm{~S}\right.$, etc) and commercially available GYY4137 can be used for $\mathrm{H}_{2} \mathrm{~S}$ delivery, but they suffer from uncontrollable releasing efficiency and imaging inability, which limits their application in cells. So far, some synthetic donors have been reported, ${ }^{4}$ which can be activated by controllable manners, such as $\mathrm{pH}$ modulation, ${ }^{5}$ cellular amines, ${ }^{6}$ thiols, ${ }^{7}$ enzymes,${ }^{8}$ light, ${ }^{9}$ bio-orthogonal reaction, ${ }^{10}$ and reactive oxygen species (ROS). ${ }^{11}$ Despite the great

\footnotetext{
${ }^{a}$ Beijing National Laboratory for Molecular Sciences, Key Laboratory of Analytical Chemistry for Living Biosystems, Institute of Chemistry, Chinese Academy of Sciences, Beijing 100190, China.E-mail: mahm@iccas.ac.cn

${ }^{b}$ University of Chinese Academy of Sciences, Beijing 100049, China

${ }^{c}$ Department of Chemistry, Washington State University, Pullman, Washington 99164, USA

† Electronic supplementary information (ESI) available. See DOI: $10.1039 / \mathrm{c} 9 \mathrm{sc} 02323 \mathrm{~b}$
}

progresses in researching the biological roles of $\mathrm{H}_{2} \mathrm{~S}$, these donors always need additional analytical methods to verify $\mathrm{H}_{2} \mathrm{~S}$ release. Fluorescence spectroscopy has attracted much attention because of its great temporal and spatial sampling capability as well as high sensitivity. ${ }^{12}$ We envision that it should be highly favorable for in situ and real-time monitoring of $\mathrm{H}_{2} \mathrm{~S}$ release in complex biological systems if a controllable $\mathrm{H}_{2} \mathrm{~S}$ donor can release $\mathrm{H}_{2} \mathrm{~S}$ accompanied by fluorescence change. However, such $\mathrm{H}_{2} \mathrm{~S}$ donors are still rare.

Herein, we design the first ROS-triggered fluorescence $\mathrm{H}_{2} \mathrm{~S}$ donor (NAB; Fig. 1A), which is constructed by linking ROSresponsive arylboronate to the fluorophore of 3-amino- $\mathrm{N}$ butyl-1,8-naphthalimide (NAH) with thiocarbamate (Scheme S1; Fig. S1-S6†). NAB itself emits rather weak fluorescence; upon reaction with ROS, the donor NAB releases carbonyl sulfide (COS) and the strongly fluorescent NAH via a self-immolative reaction. Then COS is quickly transformed to $\mathrm{H}_{2} \mathrm{~S}$ by the ubiquitous enzyme of carbonic anhydrase (CA). As a result, $\mathrm{H}_{2} \mathrm{~S}$ delivery is achieved by NAB, concomitant with an off-on fluorescence, which can be used for in situ and real time monitoring of $\mathrm{H}_{2} \mathrm{~S}$ release in living biosystems such as cells.

\section{Results and discussion}

\section{Spectroscopic response of NAB to ROS}

The reaction of NAB with $\mathrm{H}_{2} \mathrm{O}_{2}$ was investigated in the phosphate buffer (20 mM, pH 7.4). NAB displayed a maximum 


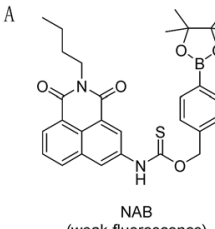

$\mathrm{NAB}$
(weak fluorescence)
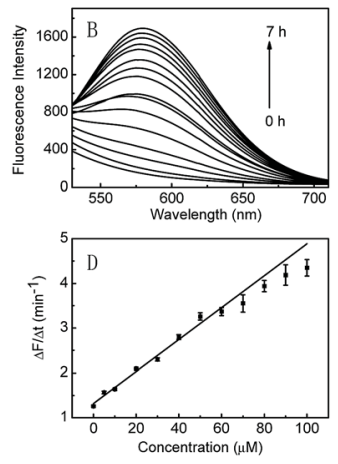

Fig. 1 (A) Response mechanism of $\mathrm{H}_{2} \mathrm{~S}$ donation from $\mathrm{NAB}$ with ROS. (B) Fluorescence spectra of $\mathrm{NAB}(10 \mu \mathrm{M})$ with $\mathrm{H}_{2} \mathrm{O}_{2}(100 \mu \mathrm{M})$ at varied time in phosphate buffer $(20 \mathrm{mM}, \mathrm{pH}$ 7.4). (C) Fluorescence kinetic curves of $\mathrm{NAB}(10 \mu \mathrm{M})$ with varied $\mathrm{H}_{2} \mathrm{O}_{2}$ (from bottom to top): 0 (control), 5, 10, 20, 50, $100 \mu \mathrm{M}$. (D) Linear fitting curve of the initial rate of fluorescence intensity changes toward the concentration of $\mathrm{H}_{2} \mathrm{O}_{2}$ in the range of $0-100 \mu \mathrm{M}$. (E) Fluorescence changes of NAB (10 $\mu M)$ in the presence of different ROS species: (1) NAB only; (2) $\mathrm{H}_{2} \mathrm{O}_{2}$ $(100 \mu \mathrm{M})$; (3) NO $(100 \mu \mathrm{M}) ;(4) \mathrm{OCl}^{-}(100 \mu \mathrm{M}) ;(5) \cdot \mathrm{OH}(100 \mu \mathrm{M}) ;(6){ }^{1} \mathrm{O}_{2}$ $(100 \mu \mathrm{M}) ;(7) \mathrm{O}_{2}{ }^{--}(100 \mu \mathrm{M}) ;(8) \mathrm{TBHP}(100 \mu \mathrm{M}) ;(9) \mathrm{TBO} \cdot(100 \mu \mathrm{M}) ;(10)$ $\mathrm{ONOO}^{-}(10 \mu \mathrm{M}) \cdot \lambda_{\mathrm{ex} / \mathrm{em}}=405 / 577 \mathrm{~nm}$.

absorption at $300 \mathrm{~nm}$, and the corresponding fluorophore NAH displayed two absorption peaks at $346 \mathrm{~nm}$ and $405 \mathrm{~nm}$ (Fig. S7A $\dagger$ ). However, addition of $\mathrm{H}_{2} \mathrm{O}_{2}$ to $\mathrm{NAB}$ caused a remarkable decrease of the absorption peak at $300 \mathrm{~nm}$, accompanying the formation of a spectrum similar to that of $\mathrm{NAH}$ (Fig. S7A $\dagger$ ). Moreover, NAB itself produced faint fluorescence signal under the excitation wavelength of $405 \mathrm{~nm}$, and its reaction solution with $\mathrm{H}_{2} \mathrm{O}_{2}$ showed a fluorescence emission peak at $577 \mathrm{~nm}$, which is in agreement with the fluorescence spectrum of $\mathrm{NAH}$ (Fig. S7B $\dagger$ ). The reaction products of NAB with $\mathrm{H}_{2} \mathrm{O}_{2}$ were further analyzed by mass spectrum. As depicted in Fig. S8, $\uparrow$ the ESI-MS spectrum of the reaction solution shows a mass peak at $m / z=267.2\left([\mathrm{M}-\mathrm{H}]^{-}\right)$, which is the same as that of NAH. The above results clearly indicate that the reaction of NAB with $\mathrm{H}_{2} \mathrm{O}_{2}$ yields the strongly fluorescent NAH.

It was noted that the conversion of NAB to NAH was incomplete even after $7 \mathrm{~h}$ according to the spectra of NAH (Fig. S7 $\dagger$ ). Furthermore, the time-dependent fluorescence responses of NAB to varied $\mathrm{H}_{2} \mathrm{O}_{2}$ also revealed that NAB could be used as a controllable $\mathrm{H}_{2} \mathrm{~S}$ donor by $\mathrm{H}_{2} \mathrm{O}_{2}$ (Fig. 1). The initial rate of fluorescence increase at varied concentrations of $\mathrm{H}_{2} \mathrm{O}_{2}$ displayed good linearity with an equation of $\Delta F / \Delta t=0.0357 \times$ $\left[\mathrm{H}_{2} \mathrm{O}_{2}\right](\mu \mathrm{M})+1.32(R=0.990)$ in the range of $0-100 \mu \mathrm{M} \mathrm{H}_{2} \mathrm{O}_{2}$ (Fig. 1D). The lowest triggering concentration of $\mathrm{H}_{2} \mathrm{O}_{2}$ that NAB needed was $2.21 \mu \mathrm{M}(k=3)$, which was higher than the reported physiological concentration (usually $\leq 0.7 \mu \mathrm{M}$ ) of intracellular
$\mathrm{H}_{2} \mathrm{O}_{2},{ }^{13}$ implying that NAB was probably unable to deliver $\mathrm{H}_{2} \mathrm{~S}$ at the normal level of intracellular $\mathrm{H}_{2} \mathrm{O}_{2}$ with the exception of some situations over $2.21 \mu \mathrm{M} \quad \mathrm{H}_{2} \mathrm{O}_{2}$ caused by other stimulations.

The effects of $\mathrm{pH}$ and temperature were also studied. As shown in Fig. $\mathrm{S} 9, \dagger$ the reaction between NAB and $\mathrm{H}_{2} \mathrm{O}_{2}$ remains inert under the acidic environment, but the fluorescence intensity is dramatically increased along with the rise in $\mathrm{pH}$ value. It might be due to the fact that alkaline media could accelerate the hydrolysis of the aryl-boronic esters to the corresponding phenols. ${ }^{14}$ Although higher temperature was favorable for the reaction, NAB also worked effectively under the physiological conditions $\left(37^{\circ} \mathrm{C}, \mathrm{pH} 7.4\right)$.

Then we tested the fluorescent response of NAB to various ROS. As depicted in Fig. 1E, NAB exhibits the strongest response to $\mathrm{H}_{2} \mathrm{O}_{2}$ over the other ROS, among which $\mathrm{O}_{2}{ }^{-}$- showed some response because it is the precusor of $\mathrm{H}_{2} \mathrm{O}_{2} \cdot{ }^{15}$ This indicates that ROS, in particular their representative $\mathrm{H}_{2} \mathrm{O}_{2}$ (the most abundant one in cells), ${ }^{16}$ can effectively trigger the $\mathrm{H}_{2} \mathrm{~S}$ release of NAB. The selectivity of NAB was examined over other potential interfering species in living cells, such as inorganic salts $\left(\mathrm{KCl}, \mathrm{MgCl}_{2}, \mathrm{CaCl}_{2}, \mathrm{ZnCl}_{2}\right.$ ), glucose, vitamin $\mathrm{C}$, glutathione and amino acids (glycine, cysteine, lysine, glutamic acid and alanine). As shown in Fig. S10, $\uparrow$ NAB displays high selectivity for $\mathrm{H}_{2} \mathrm{O}_{2}$ over the other tested species.

\section{Methylene blue colorimetric method for $\mathrm{H}_{2} \mathrm{~S}$ detection}

To verify if the decomposed product of NAB could be converted to $\mathrm{H}_{2} \mathrm{~S}$ in the presence of CA, the well-known methylene blue method ${ }^{11}$ was used to measure the $\mathrm{H}_{2} \mathrm{~S}$ generation, by which the generation of $\mathrm{H}_{2} \mathrm{~S}$ can be proved by the formation of methylene blue that has a characteristic absorption peak at $670 \mathrm{~nm}$. As shown in Fig. S11, $\uparrow$ the mixture of the MB solution and the NAB solution with $\mathrm{H}_{2} \mathrm{O}_{2}$ indeed produces an apparent absorption peak at $670 \mathrm{~nm}$, clearly indicating the $\mathrm{H}_{2} \mathrm{~S}$ release by NAB. However, when acetazolamide, a CA inhibitor, was added to the reaction system, the absorbance at $670 \mathrm{~nm}$ was significantly suppressed, revealing that the $\mathrm{H}_{2} \mathrm{~S}$ release of NAB was dependent on CA in the COS-to- $\mathrm{H}_{2} \mathrm{~S}$ conversion.

Based on the $\mathrm{H}_{2} \mathrm{~S}$ calibration curve (Fig. S11B $\dagger$ ), 10, 20 and 30 $\mu \mathrm{M}$ of NAB could generate 2.3, 3.6 and $5.0 \mu \mathrm{M}$ of $\mathrm{H}_{2} \mathrm{~S}$, respectively, within $7 \mathrm{~h}$, revealing a non-quantitative $\mathrm{H}_{2} \mathrm{~S}$ release of $\mathrm{NAB}$. The reason for this phenomenon may be complicated, but $\mathrm{H}_{2} \mathrm{O}_{2}$ may be one of the influence factors. As shown in Fig. S12, $\dagger$ more $\mathrm{H}_{2} \mathrm{O}_{2}(>100 \mu \mathrm{M})$ can cause a significant decrease of absorbance at $670 \mathrm{~nm}$. Thus, a further study on $\mathrm{H}_{2} \mathrm{O}_{2}$ effect was made. The influence of $\mathrm{H}_{2} \mathrm{O}_{2}$ on $\mathrm{MB}$ itself was excluded first (Fig. S13†). Then, $10 \mu \mathrm{M} \mathrm{Na}{ }_{2} \mathrm{~S}$ solution was mixed with varied $\mathrm{H}_{2} \mathrm{O}_{2}(100-300 \mu \mathrm{M})$ for $0.5 \mathrm{~h}$ and the mixture was transferred to the MB solution for measurement. As depicted in Fig. S14, $\dagger$ the $\mathrm{MB}$ formation is inhibited significantly, and this inhibition is $\mathrm{H}_{2} \mathrm{O}_{2}$ - and time-dependent. For instance, prolonging the reaction time between $\mathrm{Na}_{2} \mathrm{~S}$ and $300 \mu \mathrm{M} \mathrm{H}_{2} \mathrm{O}_{2}$ to $7 \mathrm{~h}$ resulted in the decrease of absorbance at $670 \mathrm{~nm}$ nearly to zero (Fig. S14 $\dagger$ ), which suggested that $\mathrm{H}_{2} \mathrm{O}_{2}$ may deplete $\mathrm{H}_{2} \mathrm{~S}$ in this case, probably via an oxidizing action. Conversely, such an action 
means that the released $\mathrm{H}_{2} \mathrm{~S}$ from NAB may scavenge $\mathrm{H}_{2} \mathrm{O}_{2}$, thereby relieving the oxidative stress.

\section{Cytotoxicity of NAB}

The toxicity of NAB was evaluated with HeLa and RAW264.7 cells (these two kinds of cell lines were obtained from Nanjing KeyGEN BioTECH Co., LTD, China) by standard MTT assay. As shown in Fig. $\mathrm{S} 15 \dagger, \dagger$ cell viability of both cell lines is not significantly affected by the incubation with NAB for $24 \mathrm{~h}$, suggesting the good biocompatibility of the donor.

\section{Fluorescence imaging of $\mathrm{H}_{2} \mathrm{~S}$ release in living cells}

As mentioned above, reaction of NAB with $\mathrm{H}_{2} \mathrm{O}_{2}$ can produce fluorescence off-on response, thus this behavior was investigated to image the $\mathrm{H}_{2} \mathrm{~S}$ release from the donor in living cells. As shown in Fig. S16, $\uparrow$ the NAB-loaded HeLa cells scarcely exhibit fluorescence, but display a gradually increased fluorescence with time upon addition of $\mathrm{H}_{2} \mathrm{O}_{2}$. Moreover, the fluorescence became much brighter when the concentration of $\mathrm{H}_{2} \mathrm{O}_{2}$ was elevated from $50 \mu \mathrm{M}$ to $100 \mu \mathrm{M}$ (Fig. 2). Nevertheless, after pretreated with NAC (an antioxidant to scavenge $\mathrm{H}_{2} \mathrm{O}_{2}$ ), the cells exhibited significantly decreased fluorescence (Fig. 2B). These results demonstrate the triggering ability of ROS in the fluorescence signal of NAB in cells.

To verify the intracellular ROS-triggered $\mathrm{H}_{2} \mathrm{~S}$ release, a commercially available probe (WSP-1), whose fluorescence can be selectively turned on by $\mathrm{H}_{2} \mathrm{~S},{ }^{17}$ was used for the detection

A

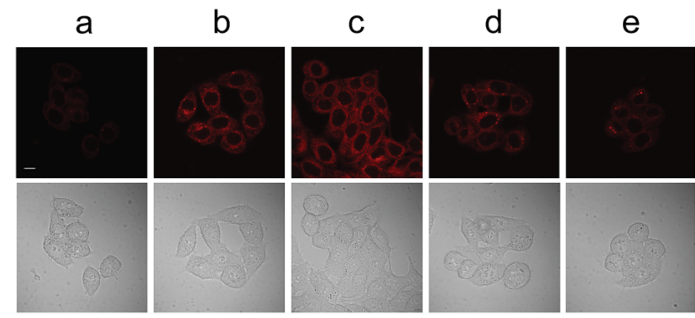

B

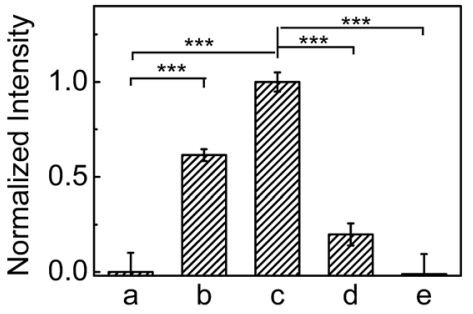

Fig. 2 (A) Confocal fluorescence images of HeLa cells. Cells incubated with NAB $(10 \mu \mathrm{M})$ for $4 \mathrm{~h}$ in the presence of (a) 0 , (b) 50, and (c) $100 \mu \mathrm{M}$ $\mathrm{H}_{2} \mathrm{O}_{2}$; cells pretreated with $\mathrm{H}_{2} \mathrm{O}_{2}(100 \mu M)$ in the presence of (d) 100 $\mu \mathrm{M}$ and (e) $1 \mathrm{mM} \mathrm{NAC}$ for $10 \mathrm{~min}$, and then incubated with NAB $(10 \mu \mathrm{M})$ for $4 \mathrm{~h}$. Scale bar: $10 \mu \mathrm{m}$. The second row is the corresponding differential interference contrast (DIC) images. (B) The normalized intensity of the corresponding images in panel $A$ [the pixel intensity is obtained by subtracting that (control) from image a; the fluorescence intensity from image $c$ is defined as 1.0]. The results are the mean \pm standard deviation of five cells. ${ }^{* * *} p<0.001$, two-sided Student's $t$ test. of $\mathrm{H}_{2} \mathrm{~S}$ in HeLa cells. As shown in Fig. S17 (images c-e), $\dagger$ the fluorescence of WSP-1 in the green channel rises with increasing the dose of $\mathrm{NAB}$ in the presence of $\mathrm{H}_{2} \mathrm{O}_{2}$, suggesting the generation of the gradually increased $\mathrm{H}_{2} \mathrm{~S}$. However, the fluorescence signal was largely attenuated when the cells were incubated with much more $\mathrm{H}_{2} \mathrm{O}_{2}$ (Fig. S18 $\dagger$ ), which is consistent with the aforementioned $\mathrm{MB}$ test results, that is, the released $\mathrm{H}_{2} \mathrm{~S}$ from NAB may be consumed by excess $\mathrm{H}_{2} \mathrm{O}_{2}$. These results validated $\mathrm{NAB}$ as the fluorescence donor for $\mathrm{H}_{2} \mathrm{~S}$ delivery, and suggested that our dual-functional donor could be used as a fluorescent probe for real time monitoring of the $\mathrm{H}_{2} \mathrm{~S}$ release in cells.

\section{$\mathrm{H}_{2} \mathrm{~S}$ release by endogenous ROS in living cells}

To evaluate the ability of NAB to release $\mathrm{H}_{2} \mathrm{~S}$ via endogenous ROS in living cells, RAW264.7 cells were chosen as a model because they are believed to generate a considerable amount of ROS in inflammatory pathology induced by PMA. ${ }^{18}$ As shown in Fig. 3, RAW264.7 cells pretreated with PMA for $1 \mathrm{~h}$ and then with NAB for $4 \mathrm{~h}$ display a remarkable fluorescence increase when compared to the control group without PMA, and the fluorescence further increases with the treatment of more PMA. This indicates that NAB can release $\mathrm{H}_{2} \mathrm{~S}$ via the endogenous ROS. Similarly, such a fluorescence increase can be efficiently inhibited by NAC, which is consistent with the above results in HeLa cells. Taking together, NAB may be capable of releasing $\mathrm{H}_{2} \mathrm{~S}$ under pathological ROS levels and in situ imaging this event in cells.

A
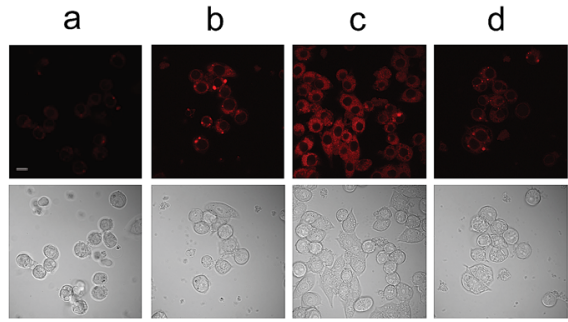

e

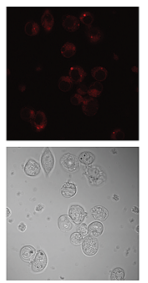

B

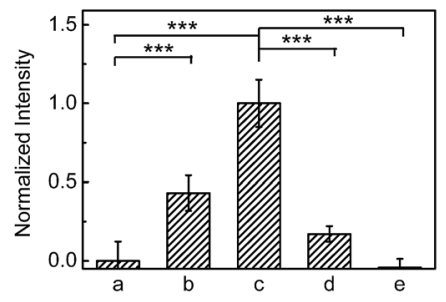

Fig. 3 (A) Confocal fluorescence images of RAW264.7 cells under different conditions. (a) Cells incubated with NAB (10 $\mu \mathrm{M})$ for $4 \mathrm{~h}$; cells pre-treated with (b) 0.5 and (c) $1 \mu \mathrm{g} \mathrm{mL} \mathrm{mL}^{-1} \mathrm{PMA}$ for $1 \mathrm{~h}$ and then incubated with NAB $(10 \mu \mathrm{M})$ for $4 \mathrm{~h}$; cells pre-treated with PMA (1 $\mu \mathrm{g}$ $\mathrm{mL}^{-1}$ ) in the presence of (d) $100 \mu \mathrm{M}$ and (e) $1 \mathrm{mM} \mathrm{NAC}$ for $1 \mathrm{~h}$ and then incubated with NAB $(10 \mu \mathrm{M})$ for $4 \mathrm{~h}$. Scale bar: $10 \mu \mathrm{m}$. (B) Normalized intensity of the fluorescence images in panel $A$ [the pixel intensity is obtained by subtracting that (control) from image a; the fluorescence intensity from image $c$ is defined as 1.0]. The results are presented as mean \pm standard deviation of five cells. ${ }^{* * *} p<0.001$, two-sided Student's $t$-test. 

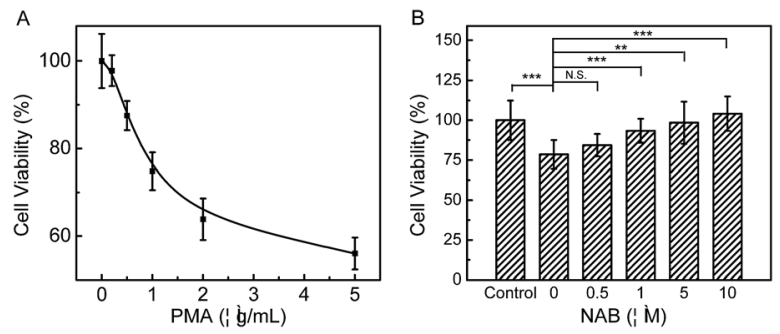

Fig. 4 Cell viability of RAW264.7 cells. (A) Cells treated with PMA at varied concentrations for $1 \mathrm{~h}$; (B) cells treated with PMA $\left(1 \mu \mathrm{g} \mathrm{mL}^{-1}\right)$ for $1 \mathrm{~h}$ and then incubated with NAB at varied concentrations for $4 \mathrm{~h}$. Control is the untreated cells. The results are the mean \pm standard deviation of five separate measurements. $* * * p<0.001,{ }^{* *} p<$ 0.01, N.S.: no significance, $p>0.01$, two-sided Student's $t$-test.

\section{Protective effect of NAB against cellular inflammation}

Since PMA induced inflammation can promote apoptosis through excess oxidative stress in cells, and $\mathrm{H}_{2} \mathrm{~S}$ has been discovered to alleviate inflammatory response effectively, as a proof of concept, we investigated the protective effect of NAB against inflammation on RAW264.7 cells. As shown in Fig. 4A, after cells are exposed to varied concentrations of PMA for $1 \mathrm{~h}$, the MTT assay manifests that $1 \mu \mathrm{g} \mathrm{mL} \mathrm{L}^{-1}$ PMA could lead to an about $25 \%$ decrease in the cell viability as compared to the control. However, the cells exposed to PMA can significantly recover their viability after they are incubated with $\mathrm{NAB}$, and this viability recovery is increased as the dose of NAB rises. A negative control experiment was also conducted by treating cells with NAH under the same PMA conditions (Fig. S19†), which demonstrates that NAH cannot protect RAW264.7 cells from the stimulation of PMA. Moreover, the ROS scavenging capacity (an anti-inflammatory behavior) of NAB was observed via monitoring the intracellular ROS change with a commercial dye CRDR (Fig. S20 $\dagger$ ). All the above findings disclose that NAB could rescue RAW264.7 cells from PMA induced cellular inflammation possibly via scavenging $\mathrm{H}_{2} \mathrm{O}_{2}$, and might serve as a potential therapeutic $\mathrm{H}_{2} \mathrm{~S}$ donor.

\section{Conclusions}

In summary, we have reported $\mathrm{NAB}$ as the first ROS-triggered off-on fluorescent $\mathrm{H}_{2} \mathrm{~S}$ donor. $\mathrm{H}_{2} \mathrm{~S}$ release from NAB was detected in both aqueous buffer and live cells. Unlike the previous reported $\mathrm{H}_{2} \mathrm{~S}$ donors, NAB can achieve $\mathrm{H}_{2} \mathrm{~S}$ release with a concomitant off-on fluorescence after activated by ROS. More importantly, using $\mathrm{NAB}$, we demonstrated the real-time imaging of $\mathrm{H}_{2} \mathrm{~S}$ delivery and the cytoprotection against ROS in RAW264.7 cells. The developed fluorescent donor may find a wide use in the delivery and real-time monitoring studies of $\mathrm{H}_{2} \mathrm{~S}$ in some biosystems.

\section{Conflicts of interest}

There are no conflicts to declare.

\section{Acknowledgements}

This work is supported by grants from the NSF of China (No. 21820102007, 21675159, 21535009, 91732104, 21775152, 21435007 and 21621062), the Chinese Academy of Sciences (Grant XDB14030102), and Youth Innovation Promotion Association of CAS (2016027).

\section{Notes and references}

1 M. W. Zhang, G. Yang, Y. F. Zhou, C. Qian, M. D. Mu, Y. Ke and Z. M. Qian, J. Cell. Physiol., 2019, 234, 3158-3169.

2 (a) L. Li, M. Whiteman, Y. Y. Guan, K. L. Neo, Y. Cheng, S. W. Lee, Y. Zhao, R. Baskar, C. H. Tan and P. K. Moore, Circulation, 2008, 117, 2351-2360; (b) M. Kuksis, P. M. Smith and A. V. Ferguson, PLoS One, 2014, 9, e105772.

3 A. P. Lan, X. X. Liao, L. Q. Mo, C. T. Yang, Z. L. Yang, X. Y. Wang, F. Hu, P. X. Chen, J. Q. Feng, D. D. Zheng and L. C. Xiao, PLoS One, 2011, 6, e25921.

4 (a) C. Szabo and A. Papapetropoulos, Pharmacol. Rev., 2017, 69, 497-564; (b) Y. Zhao, T. D. Biggs and M. Xian, Chem. Commun., 2014, 50, 11788-11805.

5 (a) J. M. Kang, Z. Li, C. L. Organ, C. M. Park, C. T. Yang, A. Pacheco, D. F. Wang, D. J. Lefer and M. Xian, J. Am. Chem. Soc., 2016, 138, 6336-6339; (b) Y. Zhao, A. K. Steiger and M. D. Pluth, Angew. Chem., Int. Ed., 2018, 57, 1310113105.

6 C. R. Powell, J. C. Foster, B. Okyere, M. H. Theus and J. B. Matson, J. Am. Chem. Soc., 2016, 138, 13477-13480.

7 (a) Y. Zhao, A. K. Steiger and M. D. Pluth, Chem. Commun., 2018, 54, 4951-4954; (b) Y. Zhao, H. Wang and M. Xian, J. Am. Chem. Soc., 2011, 133, 15-17; (c) Y. Zhao, M. M. Cerda and M. D. Pluth, Chem. Sci., 2019, 10, 1873-1878; (d) Y. Zhao, S. Bhushan, C. T. Yang, H. Otsuka, J. D. Stein, A. Pacheco, B. Peng, N. O. Devarie-Baez, H. C. Aguilar, D. J. Lefer and M. Xian, ACS Chem. Biol., 2013, 8, 12831290; (e) Y. Zhao, C. T. Yang, C. Organ, Z. Li, S. Bhushan, H. Otsuka, A. Pacheco, J. M. Kang, H. C. Aguilar, D. J. Lefer and M. Xian, J. Med. Chem., 2015, 58, 7501-7511.

8 (a) Y. Q. Zheng, B. C. Yu, Z. Li, Z. N. Yuan, C. L. Organ, R. K. Trivedi, S. M. Wang, D. J. Lefer and B. H. Wang, Angew. Chem., Int. Ed., 2017, 56, 11749-11753; (b) A. K. Steiger, M. Marcatti, C. Szabo, B. Szczesny and M. D. Pluth, ACS Chem. Biol., 2017, 12, 2117-2123.

9 (a) N. O. Devarie-Baez, P. E. Bagdon, B. Peng, Y. Zhao, C. M. Park and M. Xian, Org. Lett., 2013, 15, 2786-2789; (b) J. J. Woods, J. Cao, A. R. Lippert and J. J. Wilson, J. Am. Chem. Soc., 2018, 140, 12383-12387; (c) Y. Zhao, S. G. Bolton and M. D. Pluth, Org. Lett., 2017, 19, 2278-2281.

10 A. K. Steiger, Y. Yang, M. Royzen and M. D. Pluth, Chem. Commun., 2017, 53, 1378-1380.

11 (a) P. Chauhan, S. Jos and H. Chakrapani, Org. Lett., 2018, 20, 3766-3770; (b) Y. Zhao, H. A. Henthorn and M. D. Pluth, J. Am. Chem. Soc., 2017, 139, 16365-16376; (c) Y. Zhao and M. D. Pluth, Angew. Chem., Int. Ed., 2016, 55, 14638-14642; (d) M. D. Hartle and M. D. Pluth, Chem. Soc. Rev., 2016, 45, 6108-6117. 
12 (a) Y. C. Chen, C. C. Zhu, J. J. Cen, Y. Bai, W. J. He and Z. J. Guo, Chem. Sci., 2015, 6, 3187-3194; (b) L. W. He, X. L. Yang, K. X. Xu, X. Q. Kong and W. Y. Lin, Chem. Sci., 2017, 8, 6257-6265; (c) S. Xu, H. W. Liu, X. Yin, L. Yuan, S. Y. Huan and X. B. Zhang, Chem. Sci., 2019, 10, 320-325; (d) X. H. Li, X. H. Gao, W. Shi and H. M. Ma, Chem. Rev., 2014, 114, 590-659; (e) Z. Q. Mao, H. Jiang, Z. Li, C. Zhong, W. Zhang and Z. H. Liu, Chem. Sci., 2017, 8, 4533-4538; (f) L. Y. Wu, Y. D. Sun, K. Sugimoto, Z. L. Luo, Y. Ishigaki, K. Y. Pu, T. Suzuki, H. Y. Chen and D. J. Ye, J. Am. Chem. Soc., 2018, 140, 16340-16352; (g) B. Shi, Q. L. Yan, J. Tang, K. Xin, J. C. Zhang, Y. Zhu, G. Xu, R. C. Wang, J. Chen, W. Gao, T. L. Zhu, J. Y. Shi, C. H. Fan, C. C. Zhao and H. Tian, Nano Lett., 2018, 18, 6411-6416.

13 D. J. R. Stone and S. Yang, Antioxid. Redox Signaling, 2006, 8, 243-270.
14 L. C. Lo and C. Y. Chu, Chem. Commun., 2003, 2728-2729.

15 (a) R. H. Burdon, Free Radical Biol. Med., 1995, 18, 775-794; (b) M. Abo, Y. Urano, K. Hanaoka, T. Terai, T. Komatsu and T. Nagano, J. Am. Chem. Soc., 2011, 133, 10629-10637.

16 (a) M. C. Y. Chang, A. Pralle, E. Y. Isacoff and C. J. Chang, J. Am. Chem. Soc., 2011, 133, 15-17; (b) M. Giorgio, M. Trinei, E. Migliaccio and P. G. Pelicci, Nat. Rev. Mol. Cell Biol., 2007, 8, 722-728; (c) J. Liu, J. Ren, X. J. Bao, W. Gao, C. L. Wu and Y. B. Zhao, Anal. Chem., 2016, 88, 5865-5870.

17 C. R. Liu, J. Pan, S. Li, Y. Zhao, L. Y. Wu, C. E. Berkman, A. R. Whorton and M. Xian, Angew. Chem., Int. Ed., 2011, 50, 10327-10329.

18 J. Xu, Y. Zhang, H. Yu, X. D. Gao and S. J. Shao, Anal. Chem., 2016, 88, 1455-1461. 